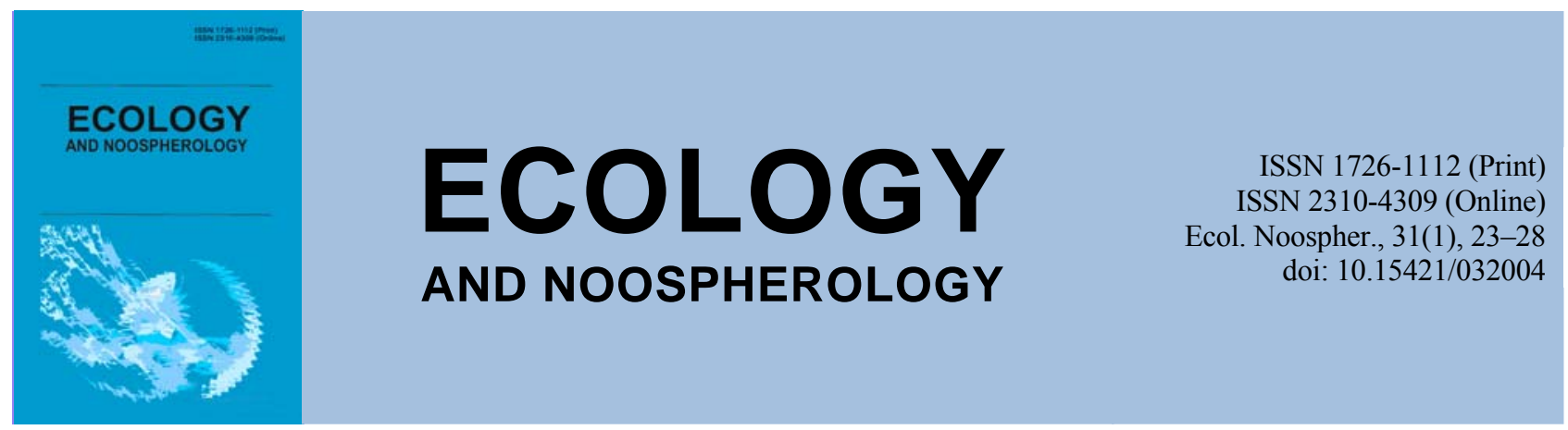

\title{
Ecological assessment of the condition of soil and field crops cultivation with application of mineral fertilizers in the conditions of the northern steppe of Ukraine
}

\author{
O. I. Tsyliuryk*, V. I. Chorna*, N. V. Voroshylova*, L. M. Desyatnik** \\ *Dnipro State Agrarian and Economic University, Dnipro, Ukraine \\ **Institute of Grain Crops of NAAS of Ukraine, Dnipro, Ukraine
}

Article info

Received 04.04.2020

Received in revised form 09.04.2020

Accepted 18.04.2020

Dnipro State Agrarian and Economic University,

st. Serhiy Yefremov, 25, Dnipro, 49027, Ukraine. Tel.: +38-050-932-91-19

E-mail:Khlyzina@ukr.net

Institute of Grain Crops of NAAS of Ukraine,

st. Volodymyr Vernadsky, 14, Dnipro, 49027, Ukraine.
Tsyliuryk, O. I., Chorna, V. I., Voroshylova, N. V., \& Desyatnik, L. M. (2020). Ecological assessment of the condition of soil and field crops cultivation with application of mineral fertilizers in the conditions of the northern steppe of Ukraine. Ecology and Noospherology, 31(1), 23-28. doi:10.15421/032004

In order to obtain a higher level of crop yields in crop rotation, there is a need to increase the application of fertilizers and pesticides, which, in turn, creates environmental problems of soil and groundwater pollution by harmful chemical elements and compounds. The purpose of the study was to study the influence of fertilizer systems with different tillage systems on the accumulation of heavy metals and nitrates in the soil and the main products of field crops. Bookmarking and conducting field experiments were carried out in accordance with generally accepted methods of research. The maximum increase in grain yield from the use of $\mathrm{N}_{48} \mathrm{P}_{18} \mathrm{~K}_{18}$ on the shelf tillage system was $-0.25(8.7 \%)$, grain units $-0.36(9.9 \%)$, feed units $-0.41(10.3 \%)$, digestible protein -0.02 $(5.0 \%) \mathrm{t} /$ ha of crop rotation area. The use of $\mathrm{N}_{48} \mathrm{P}_{18} \mathrm{~K}_{18}$ in a differentiated tillage system increased grain yield by $0.34(12.2 \%)$, grain units $-0.49(13.5 \%)$, feed units $-1.12(28.0 \%)$, digestible protein $0.06(13.6 \%)$ t/ha of crop rotation area. The use of $\mathrm{N}_{48} \mathrm{P}_{18} \mathrm{~K}_{18}$ in crop rotation with a shallow (mulching) tillage system gave an increase in grain yield by $0.38(13.6 \%)$, grain units -0.51 $(14.2 \%)$, feed units $-0.57(14.5 \%)$, digestible protein $-0.07(15.9 \%)$ t/ha of crop rotation area. According to the results of research, the highest increases in mineral fertilizers in terms of productivity were characteristic of a shallow (mulching) background with a characteristic stricter nutrient regime. Our research has not found a significant increase in the content of heavy metals and nitrates in the main and by-products of field crops when applying mineral fertilizers, because their content in the products was within acceptable concentrations. The content of nitrates in the grain of different crops ranged from 18 to $40.4 \mathrm{mg} / \mathrm{kg}$ at a maximum concentration limit of $300 \mathrm{mg} / \mathrm{kg}$. High culture of agriculture, improvement and development of new, more effective technologies of application of fertilizers in crop rotation and under each field crop taking into account soil and climatic conditions of the region, biological features of cultures and grades, specialization of crop rotations, etc. prevent environmental pollution. Rational use of mineral and organic fertilizers helps to increase soil fertility and is a major and indispensable factor in significantly increasing plant productivity and crop quality, maintaining an active biological and economic balance of nutrients without contamination of the environment with nitrates and heavy metals.

Keywords: heavy metals; nitrates; mineral fertilizers; field crops; environment; crop rotation productivity

\section{Екологічна оцінка стану грунту і польових культур сівозміни при внесенні мінеральних добрив в умовах північного степу України}

\author{
О. І. Цилюрик*, В. І. Чорна*, Н. В. Ворошилова*, Л. М. Десятник** \\ *Дніпровський державний аграрно-економічний університет, Дніпро, Україна \\ **Державна установа Інститут зернових культур НААН Украӥни, Дніпро, Украӥна
}


При внесенні мінеральних добрив не встановлено значного підвищення вмісту важких металів та нітратів в основній та побічній продукції польових культур, адже їх уміст у продукції знаходився в межах допустимих концентрацій. Уміст нітратів у зерні різних культур коливався в межах 18-40,4 мг/кг при ГДК 300 мг/кг. Упереджує забруднення навколишнього середовища висока культура землеробства, удосконалення і розробка нових, більш ефективних технологій застосування добрив у сівозміні і під кожну польову культуру з урахуванням грунтово-кліматичних умов регіону, біологічних особливостей культур і сортів, спеціалізації сівозмін тощо. Раціональне застосування мінеральних і органічних добрив сприяє підвищенню родючості грунту та є основним і незамінним фактором значного підвищення продуктивності рослин $\mathrm{i}$ якості врожаю, підтримання активного біологічного і господарського балансу поживних речовин без забруднення навколишнього середовища нітратами та важкими металами.

Ключові слова: важкі метали; нітрати; мінеральні добрива; польові культури; навколишнє середовище; продуктивність сівозмін

\section{Вступ}

Інтенсивні технології вирощування польових культур збільшують можливості забруднення грунтів залишками добрив, отрутохімікатами, гербіцидами та іншими токсикантами. Наявність токсичних речовин у грунті супроводжується їх накопиченням у продуктах харчування, кормах, поверхневих і підгрунтових водах. Тому потрібен чіткий контроль за правильним використанням добрив, пестицидів, хімічних меліорантів.

Зокрема, застосування мінеральних добрив регламентується агротехнічними $\mathrm{i}$ гігієнічними нормативами: нормою добрив на одиницю площі i співвідношенням поживних елементів для окремих культур, строками і способами внесення, максимально припустимим рівнем нітратів і нітритів у продукції рослинництва.

В умовах сьогодення розроблено чимало заходів землеробства, при яких не виникає надлишку нітратів у грунті. Серед зовнішніх чинників накопичення нітратів у продукції рослинництва головну роль відіграє рівень азотного живлення рослин. Надмірно високі дози азотних добрив здатні збільшити вміст нітратів у рослинах у $1,5-$ 8 разів порівняно 3 оптимальними та науково обгрунтованими дозами добрив, які слід коригувати відповідно до загальних запасів мінеральних форм азоту в грунті (Karmazinenko et al., 2014; Fateev, Pashchenko, 2003; Ogurtsov, Voloshin, 2003; Tkachuk et al., 2016, 2018; Yakovets, 2017).

У ННЦ «Інститут грунтознавства та агрохімії імені О. Н. Соколовського» було розроблено рекомендації щодо еколого-токсикологічного регламентування використання добрив, згідно з якими залежно від умісту азоту в грунті передбачається вносити не більше 140 кг/га азоту під пшеницю озиму (160 кг при зрошенні), 100 - під жито озиме і ячмінь ярий, 120 - кукурудзу (180 при зрошенні), 65 - гречку, 75 - просо, 170 - рис, 160 - буряк цукровий, 120 - картоплю, 90 - томати (120 при зрошенні), 60 огірки і столові буряки, 60 кг/га азоту - під моркву (Balyuk et al., 2010; Tsyliuryk, 2017).

Необхідно дотримуватись принципу збалансованого живлення між макро- i мікроелементами. За умов підвищеної небезпеки накопичення нітратів у продукції рослинництва бажано збільшувати дози фосфору та калію та вносити мікроелементи - молібден, мідь і манган, які активізують ферменти, що беруть участь у відновленні нітратів до аміаку.

Враховуючи вищевикладене, бажано якомога ширше застосовувати внесення азотних добрив частинами, у строгій відповідності до потреб польових культур згідно 3 основними етапами органогенезу, використовуючи дані грунтово-рослинної діагностики. Слід також приділяти більше уваги способам внесення добрив. Зокрема, локальне їх внесення у грунт сприяє зниженню втрат газоподібних сполук азоту в 1,5-2 рази, що посилюється гальмуванням нітрифікації внаслідок дії високої концентрації солей у стрічці добрив на життєдіяльність нітрифікуючих мікроорганізмів. Зважаючи на важливість та актуальність досліджень, їх і надалі слід продовжувати в даному напрямку 3 метою зменшення забруднення навколишнього середовища Степу України.

\section{Матеріали та методи досліджень}

Експериментальні дослідження виконували протягом 2010-2015 pp. у стаціонарному польовому досліді Державного підприємства «Дослідне господарство “Дніпро” Державної установи Інституту зернових культур НААН України», яке розташоване в південно-східній частині Придніпровської височини (130 м над рівнем моря). За прийнятим агрокліматичним розподілом ця територія відноситься до північної підзони Степу України 3 недостатнім і нестійким зволоженням.

Основними грунтотворними породами в районі діяльності Дослідного господарства $є$ бурувато-палеві леси, порівняно рихлі, карбонатні. Грунт дослідної ділянки чорнозем звичайний важкосуглинковий із умістом гумусу в шарі 0-30 см - 4,2\%, нітратного азоту - 13,2, рухомих форм фосфору і калію (за Чириковим) відповідно 145 і 115 мг/кг.

Закладення i проведення польових дослідів здійснювали відповідно до загальноприйнятої методики дослідної справи.

У п’ятипільній короткоротаційній сівозміні: чистий пар пшениця озима - соняшник - ячмінь ярий - кукурудза із загальнофоновим залишенням післяжнивних решток всіх польових культур. У сівозміні вивчали ефективність систем полицевого, диференційованого та мульчувального обробітку грунту.

Схема досліду включала різні варіанти основного обробітку грунту і загортання післяжнивних решток, які входять до складу полицевої, диференційованої та мілкої (мульчувальної) систем обробітку в сівозміні:

1. Полицевий - плугом ПЛН-4-35 на глибину 20-22 см під ярий ячмінь і соняшник, 23-25 см під кукурудзу, 2527 см під чорний пар (восени).

2. Чизельний - канадським чизель-культиватором ConserTillPlow з C-подібними підпружиненими стійками i напівгвинтовими наральниками - чизелями шириною 90 мм 3 відстанню між собою 45 см і плоскими дисками діаметром 515 мм, поставленими прямо через кожні 20 см на глибину 14-16 см під соняшник і ярий ячмінь (восени).

3. Дисковий - бороною БДВ-3 на глибину 10-12 см під ярий ячмінь і чистий пар (восени).

4. Плоскорізний - комбінованим агрегатом КШН-5,6 або КР-4,5 на глибину 14-16 см під кукурудзу (восени) та 12-14 см під соняшник (восени) та в ранньому пару (весною).

Догляд за чорним паром базувався на засадах мінімізації і різноглибинності обробітку від 10-12 см навесні до 6-8 см перед сівбою пшениці. Догляд за раннім паром після проведення основного обробітку навесні здійснювався по типу чорного.

Агротехніка вирощування польових культур (пшениця озима - сорт Литанівка, кукурудза на зерно - гібрид Білозірський 295 СВ, соняшник - гібрид Ясон, ячмінь ярий сорт Ілот) - загальноприйняті для зони Степу. На пшениці озимій та ячмені ярому у фазу кущіння застосовували гербіцид Естерон 1,2 та 0,8 л/га відповідно, на кукурудзі та соняшнику - грунтовий гербіцид Харнес у дозі 2,5 л/га. Мінеральні добрива $\left(\mathrm{N}_{30} \mathrm{P}_{30} \mathrm{~K}_{30}\right)$ під пшеницю озиму вносили восени перед сівбою, $\mathrm{N}_{30}$ додатково для 
підживлення рослин навесні у фазу трубкування. При вирощуванні кукурудзи, соняшнику i ячменю ярого мінеральні добрива $\left(\mathrm{N}_{30} \mathrm{P}_{30} \mathrm{~K}_{30}, \mathrm{~N}_{60} \mathrm{P}_{30} \mathrm{~K}_{30}\right)$ були внесені під передпосівну культивацію.

У досліді проводили ряд аналізів і обліків, зокрема вміст нітратів в основній продукції спектрофотометрично (Borisova, 1968). Валові та рухомі форми мікроелементів в грунті та рослинах визначали на приладі AAS-1 атомноадсорбційним методом.

Мета дослідження полягала у вивченні впливу систем удобрення при різних системах обробітку грунту на накопичення важких металів та нітратів у грунті та основній продукції польових культур.

\section{Результати та їх обговорення}

У різних грунтово-кліматичних умовах України продуктивність сівозмін, на думку I. С. Годуляна (Godulyan, 1974), є основним показником їх раціонального використання, доцільності та ефективності. Продуктивність залежить від взаємодії багатьох факторів: погодних умов, типу грунту, родючості, внесених добрив, набору польових культур та їх чергування, технології вирощування, системи обробітку грунту. Сукупна дія різних факторів, у тому числі і системи обробітку грунту та мульчування, за впливом на загальну продуктивність сівозмін вивчена недостатньо, але не викликає сумніву той факт, що основний шлях підвищення продуктивності полягає в насиченні високоврожайними зерновими культурами за умови збереження родючості грунтів, економії енергетичних та матеріальних ресурсів, стабільності екологічного стану довкілля в цілому.

Продуктивність п'ятипільної зерно-паро-просапної сівозміни визначалася головним чином внесеними мінеральними добривами, ніж обробітком грунту (табл. 1). Системи основного обробітку грунту на удобрених мінеральними добривами ділянках разом з післяжнивними рештками виявилися рівноцінними за всіма показниками продуктивності: вихід зерна $(2,80-2,90$ т/га), зернових одиниць $(3,59-3,64$ т/га), кормових одиниць $(3,92-$ 3,99 т/га) та перетравного протеїну $(0,41-0,44$ т/га) на один гектар сівозмінної площі 3 невеликою тенденцією до зниження показників за мілкої мульчувальної системи обробітку. На варіанті з післяжнивними рештками без мінеральних добрив перевагу за всіма показниками продуктивності мала система полицевого та диференційованого обробітку грунту внаслідок кращого поживного режиму (табл. 1). Так, вихід зерна за полицевої системи обробітку грунту тут був вищим на 0,20 т/га (7,6 \%), зернових одиниць - на $0,18(5,5 \%)$, кормових одиниць на $0,22(6,2 \%)$, перетравного протеїну - на 0,03 т/га сівозмінної площі $\quad(7,5 \%)$ порівняно 3 мілкою мульчувальною.

Внесені мінеральні добрива в помірних дозах $\left(\mathrm{N}_{24} \mathrm{P}_{18} \mathrm{~K}_{18}, \mathrm{~N}_{48} \mathrm{P}_{18} \mathrm{~K}_{18}\right.$ в середньому на 1 га сівозмінної площі) разом 3 післяжнивними рештками суттєво підвищували продуктивність сівозміни в цілому. Максимальна прибавка виходу зерна від застосування $\mathrm{N}_{48} \mathrm{P}_{18} \mathrm{~K}_{18}$ за полицевої системи обробітку становила $-0,25$ $(8,7 \%)$, зернових одиниць - 0,36 $(9,9 \%)$, кормових одиниць - 0,41 (10,3\%), перетравного протеїну - 0,02 (5,0 \%) т/га сівозмінної площі. Застосування $\mathrm{N}_{48} \mathrm{P}_{18} \mathrm{~K}_{18}$ при диференційованій системі обробітку підвищувало вихід зерна на $0,34(12,2 \%)$, зернових одиниць - 0,49 (13,5\%), кормових одиниць - 1,12 (28,0 \%), перетравного протеїну $0,06 \quad(13,6 \%)$ т/га сівозмінної площі. Використання $\mathrm{N}_{48} \mathrm{P}_{18} \mathrm{~K}_{18}$ в сівозміні за мілкої (мульчувальної) системи обробітку давало прибавку виходу зерна на 0,38 (13,6 \%), зернових одиниць $-0,51(14,2 \%)$, кормових одиниць $-0,57$ $(14,5 \%)$, перетравного протеїну - 0,07 (15,9 \%) т/га сівозмінної площі. Згідно 3 результатами досліджень найвищі прибавки від мінеральних добрив за показниками продуктивності були характерні для мілкого (мульчувального) фону 3 характерним більш жорстким

\section{Таблиця 1}

Вплив систем основного обробітку грунту та удобрення на продуктивність короткоротаційної зерно-паро-просапної сівозміни в середньому за 2010-2015 pp., т/га

\begin{tabular}{|c|c|c|c|c|c|c|c|c|c|}
\hline \multirow{3}{*}{$\begin{array}{c}\text { Послідов- } \\
\text { ність культур } \\
\text { в сівозміні }\end{array}$} & \multicolumn{9}{|c|}{ Система обробітку грунту та удобрення в сівозміні } \\
\hline & \multicolumn{3}{|c|}{ полицева } & \multicolumn{3}{|c|}{ диференційована } & \multicolumn{3}{|c|}{ мульчувальна } \\
\hline & $\begin{array}{l}\text { післяжнивні } \\
\text { рештки }\end{array}$ & $\begin{array}{c}\text { i післяжнивні } \\
\text { рештки + } \\
\mathrm{N}_{24} \mathrm{P}_{18} \mathrm{~K}_{18} \\
\end{array}$ & $\begin{array}{c}\text { післяжнивні } \\
\text { рештки }+ \\
\mathrm{N}_{48} \mathrm{P}_{18} \mathrm{~K}_{18} \\
\end{array}$ & $\begin{array}{l}\text { післяжнивні } \\
\text { рештки }\end{array}$ & $\begin{array}{c}\text { i післяжнивні } \\
\text { рештки + } \\
\mathrm{N}_{24} \mathrm{P}_{18} \mathrm{~K}_{18} \\
\end{array}$ & $\begin{array}{c}\text { післяжнивні } \\
\text { рештки }+ \\
\mathrm{N}_{48} \mathrm{P}_{18} \mathrm{~K}_{18} \\
\end{array}$ & $\begin{array}{c}\text { післяжнивні } \\
\text { рештки }\end{array}$ & 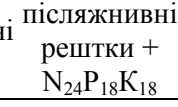 & $\begin{array}{c}\text { післяжнивні } \\
\text { рештки + } \\
\mathrm{N}_{48} \mathrm{P}_{18} \mathrm{~K}_{18} \\
\end{array}$ \\
\hline Чистий пар & - & - & - & - & - & - & - & - & - \\
\hline $\begin{array}{l}\text { Пшениця } \\
\text { озима }\end{array}$ & 5,01 & 5,14 & 5,21 & 5,01 & 5,38 & 5,49 & 4,79 & 5,02 & 5,31 \\
\hline Соняшник & 2,40 & 2,56 & 2,66 & 2,27 & 2,56 & 2,70 & 2,33 & 2,60 & 2,73 \\
\hline Ячмінь ярий & 2,78 & 2,93 & 3,13 & 2,59 & 2,87 & 3,10 & 2,23 & 2,56 & 2,88 \\
\hline Кукурудза & 5,31 & 5,75 & 6,02 & 5,23 & 5,64 & 5,91 & 5,12 & 5,53 & 5,84 \\
\hline \multicolumn{10}{|c|}{ Одержано на 1 га сівозмінної площі, т } \\
\hline Усього зерна & 2,62 & 2,76 & 2,87 & 2,56 & 2,77 & 2,90 & 2,42 & 2,62 & 2,80 \\
\hline $\begin{array}{l}\text { У тому числі } \\
\text { пшениці } \\
\text { озимої }\end{array}$ & 1,00 & 1,02 & 1,04 & 1,00 & 1,07 & 1,09 & 0,96 & 1,00 & 1,06 \\
\hline $\begin{array}{l}\text { Фуражного } \\
\text { зерна }\end{array}$ & 1,61 & 1,73 & 1,83 & 1,52 & 1,70 & 1,80 & 1,47 & 1,61 & 1,74 \\
\hline $\begin{array}{l}\text { Урожайність } \\
\text { зернових }\end{array}$ & 4,36 & 4,60 & 4,78 & 4,27 & 4,63 & 4,83 & 4,04 & 4,37 & 4,67 \\
\hline $\begin{array}{l}\text { Вихід } \\
\text { кормових } \\
\text { одиниць }\end{array}$ & 3,57 & 3,80 & 3,98 & 2,87 & 3,79 & 3,99 & 3,35 & 3,65 & 3,92 \\
\hline $\begin{array}{l}\text { Вихід } \\
\text { перетравного } \\
\text { протеїну }\end{array}$ & 0,40 & 0,42 & 0,44 & 0,38 & 0,42 & 0,44 & 0,37 & 0,41 & 0,44 \\
\hline $\begin{array}{l}\text { Вихід } \\
\text { зернових }\end{array}$ & 3,26 & 3,47 & 3,62 & 3,15 & 3,46 & 3,64 & 3,08 & 3,37 & 3,59 \\
\hline
\end{tabular}


поживним режимом. Внесені тут мінеральні добрива в помірних дозах підвищують продуктивність сівозміни більше, ніж на $14 \%$ порівняно із полицевою системою обробітку 3 кращими вихідними умовами мінерального живлення.

Для отримання вищого рівня врожайності польових культур в сівозміні виникає необхідність у збільшенні норм внесення добрив і отрутохімікатів, що, в свою чергу, породжує екологічні проблеми забруднення грунту i грунтових вод шкідливими для здоров'я людини хімічними елементами і сполуками.

Існує пряма залежність між веденням землеробства на науковій основі і збереженням екології на природному, або безпечному, рівні. У біологічному землеробстві провідної ролі набувають ланки сівозмін, основне завдання яких полягає у виробництві екологічно чистої продукції рослинництва і тваринництва (Saiko, Boyko, 2002).

Концепція біологічного землеробства, яка в останні роки отримує все більшу актуальність, передбачає підсилення принципу альтернативності за рахунок біологічних факторів, за допомогою яких можна зменшити застосування хімічних засобів і при цьому знизити антропогенний вплив на навколишнє середовище.

Повний перехід на біологічне землеробство, відмова від застосування мінеральних добрив і біоцидів навряд чи доцільно через збільшення в умовах товарного виробництва дефіциту в грунті поживних речовин i наступного за цим різкого падіння врожайності. Про це свідчить i зарубіжний досвід. Кількість ферм із альтернативним землеробством невелика i становить у Швейцарії і Данії 1-2 \%, США - 1,3 \%, Нідерландах, Швеції і Франції - 0,2-0,3 \% (Boyko, Zhilkin, 2002).

Тривале систематичне внесення добрив у грунт може призвести до накопичення їх решток як у грунті, так і в продукції рослинництва, що в кінцевому підсумку негативно впливає на стан екологічної рівноваги в агроценозі.

Хімічне забруднення грунтів, зміна їх хімічного складу в результаті антропогенної діяльності викликає погіршення їх якості. Це може відбуватися і в результаті внесення мінеральних добрив, які впливають на грунтові показники: реакцію грунтового розчину, склад поглинутих катіонів, швидкість мінералізаційних процесів та ін. При внесенні добрив, особливо в надлишковій кількості, із порушенням науково обгрунтованих технологій застосування вони можуть накопичуватись у грунтовому розчині в токсичній кількості для різних мікроорганізмів $i$ рослин, а також забруднювати продукцію рослинництва, роблячи іiі непридатною для вживання в їжу людини і на корм тваринам.
Серед мінеральних добрив у першу чергу найбільшими забруднювачами $\epsilon$ азотні добрива, які сприяють накопиченню нітратів $\left(\mathrm{N}^{\left.-\mathrm{NO}_{3}\right)}\right.$ у рослинах та зерні (Kudeyarov, 1980).

Нітрати накопичуються в грунті, а потім переміщуються в рослини або вимиваються в грунтові та поверхневі води. Відповідно до стандартів Світової організації здоров'я (СО3) допустима кількість нітратного азоту в питній воді може варіювати в межах від 11,3 до 22,6 мг/л $\mathrm{N}_{-} \mathrm{NO}_{3}$. У Німеччині визначена гранична допустима концентрація (ГДК) $\mathrm{N}-\mathrm{NO}_{3}$ для питної води 20 мг/л, в США, Польщі, Україні - 10 мг/л (Bovssen, 1977; Khvoshcheva, 1979; Vulstake, Biston, 1978).

У 1961 р. сесією об'єднаного комітету ФАО/СОЗ по харчових добавках було визнано, що гранично допустимою добовою дозою нітратів для людини $є 5$ мг $\mathrm{N}-\mathrm{NO}_{3}$ на 1 кг маси тіла. У зв'язку 3 цим допустима загальна норма споживання нітратів для людини за день 500 мг $\mathrm{N}-\mathrm{NO}_{3}$. У США ця норма вища -700 мг за день. У країнах Західної Європи стандартом для вмісту азоту нітратів в овочах загальноприйнято вважати 300 мг/кг сухої речовини (Bovssen, 1977; Khvoshcheva, 1979; Vulstake, Biston, 1978)

У нашому досліді спостерігалась тенденція до збільшення кількості нітратів на удобрених ділянках. Причому із збільшенням доз добрив дещо збільшувалась і кількість нітратів у зерні. Найменша кількість нітратів виявлена на контролі без внесення добрив (табл. 2).

Однак різні дози добрив не справляли помітного впливу на їх вміст в основній i побічній продукції. У більшій мірі кількість нітратів у зерні залежала від біологічних особливостей культур. За зменшенням нітратів в основній продукції культури розподілялись в такому порядку: ячмінь, кукурудза, пшениця озима, соняшник.

Кількість нітратів на найбільш удобрених ділянках перевищувала контроль у зерні озимої пшениці - на 8,5 \%, ячменю - 4,2-17,0 \%, кукурудзи - 3,6-10,7 \%. Протягом років спостережень (2010-2015 рр.) нами не виявлено достовірної різниці у впливі попередників на вміст нітратів у зерні.

У побічній продукції на контрольному варіанті без внесення добрив уміст нітратів у соломі і листо-стебловій масі був на 50-150 мг/кг менший, ніж на удобрених ділянках. Найбільше нітратів містилося в стеблах соняшнику, а найменше - у соломі ячменю.

Уміст нітратів в основній продукції при внесенні мінеральних $\mathrm{i}$ органічних добрив не перевищував ГДК 300 мг/кг і складав в озимої пшениці - 25 мг/кг, кукурудзи 21,5, ячменю - 41,7 мг/кг.

Таблиця 2

Уміст нітратів в основній продукції польових культур

\begin{tabular}{|c|c|c|c|c|c|}
\hline \multirow{2}{*}{$\begin{array}{c}\text { Система обробітку } \\
\text { грунту }\end{array}$} & \multirow[b]{2}{*}{ Система удобрення } & \multicolumn{4}{|c|}{ Уміст $\mathrm{NO}_{3}$, мг/кг } \\
\hline & & $\begin{array}{c}\text { пшениця } \\
\text { озима (зерно) }\end{array}$ & $\begin{array}{c}\text { соняшник } \\
\text { (насіння) }\end{array}$ & $\begin{array}{l}\text { ячмінь ярий } \\
\text { (зерно) }\end{array}$ & $\begin{array}{c}\text { кукурудза } \\
\text { (зерно) }\end{array}$ \\
\hline \multirow{3}{*}{ Полицева } & Післяжнивні рештки & 19,1 & 12,1 & 34,9 & 29,2 \\
\hline & $\begin{array}{c}\text { Післяжнивні рештки } \\
+\mathrm{N}_{24} \mathrm{P}_{18} \mathrm{~K}_{18}\end{array}$ & 20,2 & 12,8 & 35,0 & 30,6 \\
\hline & $\begin{array}{c}\text { Післяжнивні рештки } \\
+\mathrm{N}_{48} \mathrm{P}_{18} \mathrm{~K}_{18}\end{array}$ & 21,4 & 13,0 & 36,9 & 31,6 \\
\hline \multirow{3}{*}{ Диференційована } & Післяжнивні рештки & 18,7 & 12,5 & 35,5 & 27,3 \\
\hline & $\begin{array}{c}\text { Післяжнивні рештки } \\
+\mathrm{N}_{24} \mathrm{P}_{18} \mathrm{~K}_{18}\end{array}$ & 19,6 & 12,7 & 36,1 & 28,1 \\
\hline & $\begin{array}{c}\text { Післяжнивні рештки } \\
+\mathrm{N}_{48} \mathrm{P}_{18} \mathrm{~K}_{18} \\
\end{array}$ & 21,2 & 13,3 & 36,8 & 30,3 \\
\hline \multirow{3}{*}{ Мульчувальна } & Післяжнивні рештки & 19,6 & 12,0 & 33,8 & 27,6 \\
\hline & $\begin{array}{c}\text { Післяжнивні рештки } \\
+\mathrm{N}_{24} \mathrm{P}_{18} \mathrm{~K}_{18}\end{array}$ & 20,1 & 12,4 & 36,0 & 28,9 \\
\hline & $\begin{array}{c}\text { Післяжнивні рештки } \\
+\mathrm{N}_{48} \mathrm{P}_{18} \mathrm{~K}_{18}\end{array}$ & 21,6 & 12,9 & 36,6 & 30,3 \\
\hline
\end{tabular}


Iз підвищенням доз добрив дещо збільшувалась кількість нітратів в основній та побічній продукції польових культур, не перевищуючи при цьому ГДК.

Окрім цього, мінеральні добрива через низький рівень очищення містять у собі фтор, стронцій, кадмій, свинець та інші мікроелементи. Так, на одну тонну $\mathrm{P}_{2} \mathrm{O}_{5}$ у деяких рудах може припадати від 80 до 100 кг фтору, 30-40 кг стронцію, 20-25 кг оксидів рідкоземельних та радіоактивних елементів. Майже 80 \% кадмію, внесеного у грунт 3 добривами, залишається в орному шарі (Khorishko, 1997).

Такі мікроелементи, як мідь, цинк, марганець, у надлишковій кількості викликають порушення росту, розвитку рослин, повну їх загибель (Ilyin, 1991).

Уміст цинку у грунті коливається в межах 10300 мг/кг, а при концентрації 100 мг/кг може відбуватися порушення розвитку рослин (Khorishko, 1997).

Польові культури також мають різну чутливість до металів-забруднювачів і сильно різняться за величиною порогу токсичності елементів навіть у межах однієї групи рослин. Найстійкіші в цьому відношенні зернові, а найбільш уразливі - овочеві культури, насамперед салат, щавель, шпинат, петрушка тощо.

Метали мають також різний поріг токсичності. Закордонними дослідниками встановлено, що для свинцю він становить 2000 мг/кг, цинку - 100-150, міді - 50-200, кадмію - 20-50 мг/кг грунту (Bovssen, 1977). До тих ГДК, що розроблені гігієністами для деяких елементів (свинець 20 ; ртуть - 2,1; арсен - 2,0; хром - 0,05; манган - 1500 мг/кг), слід ставитися критично, виходячи 3 того, що, наприклад, природний уміст свинцю в різних типах грунтів коливається від 10 до 50 мг/кг грунту (Kravchenko et al., 2002).

Важкі метали слабо переміщуються по профілю грунту, і тому вони в основному накопичуються у верхніх орних шарах грунту (Kravchenko et al., 2002; Bovssen, 1977).

Валовий уміст досліджуваних елементів у чорноземах ДПДГ «Дніпро» знаходиться в межах регіонального фону, за винятком марганцю і свинцю, уміст яких дещо вищий, але набагато нижчий ГДК (табл. 3) (Tsyliuryk, 2014).

Таблиця 3

Регіональний фон важких металів (мг/кг) та їх ГДК

\begin{tabular}{cccccccccc}
\hline Показники & $\mathrm{Zn}$ & $\mathrm{Mn}$ & $\mathrm{Cu}$ & $\mathrm{Co}$ & $\mathrm{Fe}$ & $\mathrm{Pb}$ & $\mathrm{Cr}$ & $\mathrm{Ni}$ & $\mathrm{Cd}$ \\
\hline Регіональний фон & 62,0 & 457 & 29,6 & 16,0 & 17490 & 13,2 & 52,0 & 25,0 & 0,2 \\
ГДК & 300 & 1500 & 100 & 50,0 & - & 100 & 100 & 100 & 3,0 \\
\hline
\end{tabular}

Велике значення має також контроль важких металів у продукції польових культур. Як видно з табл. 4, уміст важких металів у зерні зернових культур та насінні соняшнику знаходиться в межах норми, не перевищуючи ГДК.

\section{Таблиця 4}

Уміст мікроелементів і важких металів в основній продукції сільськогосподарських культур, мг/кг (2010-2015рp.)

\begin{tabular}{ccccccccc}
\hline Культура & Система удобрення & $\mathrm{Zn}$ & $\mathrm{Mn}$ & $\mathrm{Cu}$ & $\mathrm{Ni}$ & $\mathrm{Co}$ & $\mathrm{Pb}$ & $\mathrm{Cd}$ \\
\hline \multirow{2}{*}{ Пшениця озима } & Контроль (без добрив) & 19,7 & 21,8 & 2,1 & 0,58 & 0,33 & 0,47 & 0,017 \\
& Післяжнивні рештки $+\mathrm{N}_{48} \mathrm{P}_{18} \mathrm{~K}_{18}$ & 20,6 & 22,3 & 2,82 & 0,59 & 0,36 & 0,56 & 0,018 \\
\hline \multirow{2}{*}{ Ячмінь } & Контроль (без добрив) & 20,2 & 5,6 & 2,6 & 1,41 & 0,38 & 0,34 & 0,0075 \\
& Післяжнивні рештки $+\mathrm{N}_{48} \mathrm{P}_{18} \mathrm{~K}_{18}$ & 20,4 & 6,4 & 2,4 & 1,79 & 0,38 & 0,41 & 0,0095 \\
\hline \multirow{2}{*}{ Кукурудза } & Контроль (без добрив) & 16,6 & 2,63 & 1,18 & 0,57 & 0,24 & 0,22 & 0,009 \\
& Післяжнивні рештки $+\mathrm{N}_{48} \mathrm{P}_{18} \mathrm{~K}_{18}$ & 18,2 & 2,99 & 1,42 & 0,88 & 0,3 & 0,225 & 0,008 \\
\hline \multirow{2}{*}{ Соняшник } & Контроль (без добрив) & 35,4 & 8,2 & 6,98 & 5,43 & 0,63 & 0,43 & 0,090 \\
& Післяжнивні рештки $+\mathrm{N}_{48} \mathrm{P}_{18} \mathrm{~K}_{18}$ & 35,6 & 10,4 & 7,65 & 6,4 & 0,75 & 0,42 & 0,091 \\
\hline ГДК для харчових потреб & 50 & - & 10 & - & - & 0,5 & 0,1 \\
\hline ГДК для згодовування тваринам & 60 & - & 30 & - & - & 5,0 & 0,3 \\
\hline
\end{tabular}

Внесення добрив у нашому досліді практично не впливало на вміст рухомих мікроелементів у грунті та рослинах. I хоча кількість їх у чорноземах та рослинах суттєво нижча за гранично допустимі концентрації, виникає необхідність проводити періодичний контроль за їх умістом з метою коригування доз і складу добрив при тривалому застосуванні їх у ланках сівозмін.

\section{Висновки}

Дослідженнями не встановлено значного підвищення вмісту важких металів та нітратів в основній та побічній продукції польових культур при внесенні мінеральних добрив, адже їх уміст у продукції знаходився в межах допустимих концентрацій. Зокрема, уміст кількості нітратів у зерні різних культур коливалось у межах 1840,4 мг/кг при ГДК 300 мг/кг. У запобіганні забруднення навколишнього середовища важливу роль відіграє висока культура землеробства, удосконалення і розробка нових, більш ефективних технологій застосування добрив у сівозміні і під кожну польову культуру з урахуванням грунтово-кліматичних умов регіону, біологічних особливостей культур і сортів, спеціалізації сівозмін тощо.

Правильне застосування мінеральних i органічних добрив сприяє підвищенню родючості грунту та $\epsilon$ основним і незамінним фактором значного підвищення продуктивності рослин і якості врожаю, підтримання активного біологічного i господарського балансу поживних речовин без забруднення навколишнього середовища нітратами та важкими металами.

\section{References}

Balyuk, S. A., Medvedeva, V. V., Tarariko, O. G. (2010). Natsionalna dopovid pro stan rodyuchosti gruntiv Ukrayiny [National report on the state of soil fertility of Ukraine]. Kyiv, NAASU, NSC IGA named after O.N. Sokolovsky, NUBIP (in Ukraine).

Borisova, N. I. (1968). Spektrofotometrycheskyy metod opredelenyya nytratov $\mathrm{v}$ pochve [Spectrophotometric method for the determination of nitrates in soil]. Ahrokhymyya, 8, $148-153$ (in Russia).

Boyko, P. I., Zhilkin, V. A. (2002). Sivozminy u zemlerobstvi Ukrayiny [Crop rotation in agriculture of Ukraine]. Kyiv, Agrarian Science (in Ukraine).

Bovssen, P. (1977). Nahrs to ffaes waschung aus geaungten und ugechingten Boden. I.V. Ablrangigkeit von Standorteigen schaften und Nutrung der Moranen und Sandgebiete. Schleswing. Nolsteins, 1-177.

Fateev, A. I., Pashchenko, Ya. V. (2003). Fonovyy vmist mikroelementiv u gruntakh Ukrayiny [Background content of microelements in the soils of Ukraine]. Kharkiv, 13 printing house (in Ukraine). 
Godulyan, I. S. (1974). Ozymaya pshenytsa v sevooborotakh [Winter wheat in crop rotations]. Dnepropetrovsk, Promin (in Russia).

Ilyin, V. B. (1991). Tyazhelye metally $\mathrm{v}$ systeme pochva rastenye [Heavy metals in the soil-plant system]. Novosibirsk, Nauka (in Russia).

Karmazinenko, S. P., Kuraeva, I. V., Samchuk, A. I. (2014). Vazhki metaly $\mathrm{u}$ komponentakh navkolyshnoho seredovyshcha m. Mariupol (ekoloho-heokhimichni aspekty) [Heavy metals in the components of the environment of Mariupol (ecological and geochemical aspects)]. Kyiv, Interservis (in Ukraine).

Kudeyarov, V. N. (1980). Kruhooborot azota v pochve v svyazy s yntensyfykatsyey selskokhozyaystvennoho proyzvodstva y problemy zashchyty okruzhayushchey sredy [The nitrogen cycle in the soil due to the intensification of agricultural production and environmental problems]. Moscow, Nauka, 29-34 (in Russia).

Khorishko, A. I. (1997). Ozyma pshenytsya u sivozminakh Prydniprovya [Winter wheat in crop rotations of the Dnieper]. Dnepropetrovsk, CJSC Polygraphist (in Ukraine).

Khvoshcheva, B. G. (1979). Nakoplenye nytratov v produktsyy rastenyevodstva y vodoystochnykakh [Accumulation of nitrates in crop production and water sources. Survey information]. Moscow, All-Union Scientific Research Institute of Technical and Economic Research in Agriculture (in Russian).

Kravchenko, M. S., Zlobin, Y. A., Tsarenko, O. M. (2002). Zemlerobstvo [Agriculture]. Kyiv, Lubid (in Ukraine).

Ogurtsov, A. P., Voloshin, M. D. (2003). Modern environment and ways to improve it [Suchasne dovkillya ta shlyakhy yoho pokrashchennya]. Kyiv (in Ukraine).

Saiko, V. F., Boyko, P. I. (2002). Sivozminy u zemlerobstvi Ukrayiny [Crop rotation in agriculture of Ukraine]. Kiev, Agrarian Science (in Ukraine).
Tkachuk, O. P., Yakovets, L. A., Vatamanyuk, O. V. (2018). Intensyvnist znyzhennya kontsentratsiyi nitrativ u zerni zlakovykh kultur zalezhno vid periodu zberihannya [Intensity of reduction of concentration of nitrates in grain of cereals depending on the storage period]. Zbalansovane pryrodokorystuvannya. Kyiv, 173-175 (in Ukraine).

Tkachuk, O. P., Yakovets, L. A. (2016). Osoblyvosti zabrudnennya zernovoyi produktsiyi vazhkymy metalamy $\mathrm{v}$ umovakh Vinnytskoyi oblasti. [Features of contamination of grain products with heavy metals in the Vinnytsia region]. Silske hospodarstvo i lisivnytstvo. Vinnytsia, 4, 179-185 (in Ukraine).

Tsyliuryk, O. I. (2014). Naukove obgruntuvannya efektyvnosti system osnovnoho obrobitku gruntu v korotkorotatsiynykh sivozminakh pivnichnoho Stepu Ukrayiny [Scientific substantiation of efficiency of systems of the basic cultivation of soil in short-rotation crop rotations of northern Steppe of Ukraine]: dis. for the degree of Doctor of Agricultural Sciences Science: special. 06.01.01 "General agriculture". Dnepropetrovsk (in Ukraine).

Tsyliuryk, O. I. (2017). Zakhody dlya zmenshennya zabrudnennya gruntiv mineralnymy dobryvamy [Measures to reduce soil pollution with mineral fertilizers]. Agribusiness Today (newspaper of entrepreneurs of agro-industrial complex), 7(350), 92-95 (in Ukraine).

Vulstake, G., Biston, R. (1978). Fastons affecting nitrate content, $1,71-87$.

Yakovets, L. A. (2017). Ekolohichna nebezpeka zastosuvannya nayposhyrenishykh mineralnykh dobryv. Tekhnikotekhnolohichni aspekty rozvytku ta vyprobuvannya novoyi tekhniky i tekhnolohiy dlya silskoho hospodarstva Ukrayiny [Environmental hazards of the most common mineral fertilizers. Technical and technological aspects of development and testing of new equipment and technologies for agriculture of Ukraine]. Doslidnytske, 21(35), 298-301 (in Ukraine). 